\title{
Behavioural Problems in Adolescent Children of Alcoholics
}

\section{Alkoliklerin Ergen Çocuklarında Davranış Sorunları}

Haradanahalli Giriprakash Kshamaa', Manju Aswath ${ }^{1}$,

Padmanabha Thiruganahalli Shivaraju²

${ }^{1}$ Department of Psychiatry, Kempegowda Institute of Medical Sciences and Research Center, Rajiv Gandhi University of Health Sciences, V V Puram, Bangalore, Karnataka, India

${ }^{2}$ Department of Pharmacology,

Adichunchanagiri Institute of Medical

Sciences, Adichunchanagiri University, B G Nagara, Nagamangala taluk, Mandya district, Karnataka, India

Geliş Tarihi/Received: 14 May 2020

Kabul Tarihi/Accepted: 16 June 2020

Address correspondence to: Manju Aswath, Department of Psychiatry, Kempegowda Institute of Medical Sciences and Research Center, Rajiv Gandhi University of Health Sciences, V V Puram, Bangalore

e-mail: manjuaswath@yahoo.com

\section{ORCID}

Haradanahalli Giriprakash Kshamaa https://orcid.org/0000-0002-4035-2751 Manju Aswath

https://orcid.org/0000-0002-7075-8648 Padmanabha Thiruganahalli Shivaraju https://orcid.org/0000-0001-6085-5631

\section{Öz}

Amaç: Alkol bağımlılığı sendromu hem bireyleri hem de aileyi etkileyen önemli bir sorundur. Alkole bağımlı ebeveynlerin çocukları birçok davranış problemine karşı savunmasızdır. Batıdaki çalışmalar, bu çocuklarda hem içsel hem de dışsal semptomları göstermiştir. Bu çalışmanın amacı alkole bağımlı ebeveynlerin çocuklarında psikolojik işlevlerini ve alkol bağımlılığının şiddeti ile ilişkilerini değerlendirmektir. Hastalar ve Yöntem: Bu çalışma 2015-2017 yılları arasında Bangalore'deki bir üçüncü basamak hastanenin Psikiyatri Bölümü'nde yürütülmüştür. Alkol bağımlılığı olan 11 baba ile 18 yaş arasındaki 80 çocuk değerlendirildi. Ebeveynin ve çocuğun sosyografik demografik bilgileri yarı yapılandırılmış bir Performa tarafından bilgilendirilmiş onam alınarak toplandı. Alkol bağımlıı̆̆ının şiddeti Alkol Bağımlılığı Şiddeti Anketi (SADQ) kullanılarak değerlendirildi. Çocukların psikolojik işlevleri Gençlik Öz Raporlama Ölçeği (YSR) kullanılarak değerlendirildi.

Bulgular: Değerlendirilen 80 çocuktan $41^{\prime} i$ erkek, 39'u kadındı. \% $47.5^{\prime}$ i anlamlı içselleştirme belirtileri ve\% 48.7'si önemli dışsallaştırma belirtileri gösterdi. İçselleştirme puanları kızlarla daha yüksek korelasyona sahipti (P-0.004) ve erkeklerde dışsallaştırma semptomları (P-0.008). Ancak babada bağımlılığın şiddeti ile korelasyon bulunmadı.

Sonuç: Alkol bağımlısı babaların çocuklarında dışsallaştırma ve içselleştirme davranışları açısından psikiyatrik morbidite prevalansının yüksek olduğu bulunmuştur. Bu nedenle, bu sorunların erken teşhisi ve müdahale bu grupta daha iyi çalışmayı sağlayacaktır.

Anahtar Kelimeler: Alkolikler, Çocuk, İ̧̧levsel Olmayan Davranış, Duygusal Rahatsızlık

\section{Abstract}

Aim: Alcohol dependence syndrome is a major problem affecting both individuals and their family. Children of alcohol dependent parents are vulnerable to a host of behavioural problems. Studies in the west have shown both internalizing and externalizing symptoms in these children. This study aims to assess the psychological functioning in offspring of alcohol dependent parents and its association with severity of alcohol dependence.

Patients and Methods: This study was conducted at the Department of Psychiatry of a Tertiary hospital in Bangalore between 2015-2017. Eighty children aged 11 years - 18 years, along with their alcohol dependent fathers were included. Socio demographic details of the parent and the child were collected by a semi structured Performa along with informed consent. Alcohol dependence was diagnosed based on ICD 10 criteria. Severity of Alcohol dependence was assessed using Severity of Alcohol Dependence Questionnaire (SADQ). Psychological functioning of the children was assessed using Youth Self Report Scale (YSR).

Results: Among 80 children assessed 41 were males and 39 were females. $47.5 \%$ of them showed significant internalizing symptoms and $48.7 \%$ significant externalizing symptoms. Internalizing scores had higher correlation with girls $(P-0.004)$ and externalizing symptoms in boys $(P-0.008)$. However no correlation was found with severity of dependence in the father.

Conclusions: It was found that there was high prevalence of psychiatric morbidity in terms of externalizing and internalizing behaviours in children of alcohol dependent fathers. Thus early detection of these problems and intervention would ensure improved functioning in this group.

Key words: Alcoholics, Child, Dysfunctional Behaviour, Emotional Disturbance
Cite this article as: Kshamaa HG, Aswath M, Shivaraju PT. Behavioural Problems in Adolescent Children of Alcoholics. Selcuk Med J 2020;36(3): 244-251
Disclosure: None of the authors has a financial interest in any of the Disclosure: None of the authors has a financial interest in any of the
products, devices, or drugs mentioned in this article. The research was products, devices, or drugs mentioned in this article. The research was
not sponsored by an outside organization. All authors have agreed to allow full access to the primary data and to allow the journal to review the data if requested. 


\section{INTRODUCTION}

Alcohol dependence is a major problem in India with a prevalence of $21.4 \%$ (WHO). Alcohol dependence affects both individuals and their family. In a recent study(1) $95 \%$ - 99\% of family members of such individuals had moderate to severe burden in terms of disturbed psychological and emotional states. Children are the most affected due to parental alcohol dependence. The children of alcohol dependent parents grow up in an environment lacking parenting, with poor home management and lack of family communication skills. There is a lack of effective modelling to children by parents due to alcohol dependence(2). Parents with alcohol dependence are unable to provide a structure or discipline in family life, but simultaneously expect their children to be competent at a wide variety of tasks earlier than do non-substance abusing parents (2-5). Studies have reported that children of alcohol dependent parents are predisposed to maladjustment (6). They often have personality disturbances manifested by signs of hostility, impulsiveness, depression, and sexual confusion. These children reported depressive and anxiety symptoms more frequently than children from non-addicted families (7). There is also increased rate of Attention Deficit Hyperactivity Disorder (ADHD) and Oppositional Defiant Disorder(ODD) in them.(8) The pre-adolescent children of alcohol dependent individuals have been the main focus of most Indian studies. These studies pertain mostly to nutritional neglect, physical abuse(9), problems in emotional and social adjustments, and school dropouts(10). Studies on adolescent children of parents with alcohol dependence in west have predominantly shown both internalizing and externalizing symptoms

Indian studies looking at maladaptive behaviour in adolescent children of alcohol dependent parents are sparse. On this background, the present study takes this inquiry further to examine the psychological functioning in the children of alcohol dependent parents.

\section{PATIENTS AND METHODS}

The present cross-sectional study was conducted at the Department of Psychiatry, in a Tertiary care centre, Bangalore, India between 2015-2017. The study protocol was presented to the Ethical Review committee and was duly approved. The data was collected over the span of one year, with purposive sampling. 80 consecutive Adult males with diagnosis of Alcohol Dependence Syndrome according to ICD
10, seeking treatment at the Department of Psychiatry were included in the study. Patients with any co-morbid psychiatric diagnosis or using any other substance concurrently (except nicotine) were excluded from the study. Their children aged between 11 to 18 years were included in the study. Those children with low IQ were excluded. Written informed consent was obtained from all of them prior to recruitment into the study. Socio-demographic characteristics and clinical details of all the subjects were recorded in a semistructured proforma developed by the department of psychiatry for the study.

The severity of alcohol dependence in patients was assessed using Severity of Alcohol Dependence Questionnaire (SADQ). IQ assessment was done to the children using Binet Kamat Test and Youth Self Report was administered to children included in the study to assess psychological functioning. All scales were administered in English by the interviewer.

\section{Scales used:}

SADQ: The SADQ is a self-administered, 20item questionnaire designed to measure severity of dependence on alcohol as formulated by Stockwell et al; (1979). It includes Physical Withdrawal, Affective Withdrawal, Withdrawal Relief Drinking, Alcohol Consumption, and Rapidity of Reinstatement. Each item is scored on a four-point scale, ranging from "Almost Never" to "Nearly Always," resulting in a corresponding score of zero to three. Thus, the total maximum score possible is 60 and the minimum is zero. Based on the scores the severity ranges from no dependence to very severe dependence. A score of 31 or higher indicates "severe alcohol dependence". A score of 16 -30 indicates "moderate dependence" A score of below 16 usually indicates only a mild physical dependency. It shows good evidence of internal validity, criterion validity and external validity. (11)

Binet - Kamat Test: Binet-Kamat (B-K) test is a modified version of Stanford Binet Scale measuring intelligence of Indian children. Tests are grouped into age levels extending from 3 years to superior adult level, with six tests in each group. B-K test include both verbal and performance tests. It is both power and speed test since some of the test items are timed. The test provides an estimate of MA\& IQ. Pattern analysis of the test items provide estimate of specific cognitive functions as, comprehension, memory, reasoning and other abilities. The reliability of the Binet - Kamat test of intelligence is reportedly above 0.7 and the validity of this test for normal children against estimation of 
intelligence quotient by teachers is 0.5 (12).

Youth Self Report: The YSR is a 112-item selfreport designed for children and adolescents (ages 11-17), that assesses behavioural competency and behavioural problems and parallels the Child Behavior Checklist (CBCL). Behaviours are rated on a 3-point scale: 0-Not true, 1-Somewhat or sometimes true and 2-Very true or often true, based on the preceding 6-months. The questionnaire provides scores for the following syndrome scales: anxious/depressed, withdrawn/depressed, somatic complains, social problems, thought problems, rulebreaking behavior, and aggressive behavior. The questionnaire provides scores for the following DSMoriented scales: affective problems, anxiety problems and somatic problems grouped under internalizing behaviours, attention deficit/hyperactivity problems, oppositional defiant problems and conduct problems grouped as externalizing behaviours. There are 20 social competency items that measure the child's participation in hobbies, games, sports, jobs, chores, friendship, and activities. Percentile scores are calculated for internalizing behaviour, externalizing behaviour, total scores and competence which are then grouped under normal range and clinical range. (13)

The responses were analysed using descriptive statistics, and Chi-square test, with $P<0.05$, was considered statistically significant with the help of SPSS software.

\section{RESULTS}

Socio-demographic details of the study population were as follows. The age of alcohol dependent fathers ranged between $30-50$ years, of which ten were aged between 30 - 35 years, 23 were between $35-40$ years, 26 between $41-45$ years and 21 were between 46 - 50 years. Twenty-one of the above were illiterates whereas 25 had primary education. 27 had completed their secondary education, six had bachelors' degree and 1 had masters. The sample population belonged to various occupational strata, of which two of them were un-employed, 32 were unskilled labourers. 2 belonged to semi-skilled category, 36 were skilled labourers and eight of them were professionals.

Twenty two of the 80 alcohol dependent parents were from the rural background and 50 from urban areas. Seventy-six belonged to Hindu religion and the rest were Muslims. Duration of alcohol consumption in the study population was analysed. It showed that 4 of the fathers had history of alcohol consumption of less than 10 years, 32 between 11 - 20 years, 42 between 21 - 30 years and 2 for more than 30 years.

On SADQ mild dependence was found in 12 of the sample, 44 fulfilled the criteria for moderate dependence; severe dependence was seen in 15 of them and very severe in nine (table 1). Among the 80 children analysed 41 were male and 39 females (Table 1). Average IQ on BKT was 93.98. Raw scores of these children were assessed on YSR; $47.5 \%$

Table 1. Descriptive data of the study population

\begin{tabular}{|c|c|c|c|}
\hline Age Group: & & Residence: & \\
\hline $30-35$ & 10 & Rural & 22 \\
\hline $36-40$ & 23 & Urban & 58 \\
\hline $41-45$ & 26 & Religion: & \\
\hline $46-50$ & 21 & Hindu & 76 \\
\hline Education: & & Muslim & 4 \\
\hline Illitrate & 21 & Duration of alcohol dependence(Years): & \\
\hline Primary & 25 & $0-10$ & 4 \\
\hline Secondary & 27 & $11-20$ & 32 \\
\hline Bachelors & 6 & $21-30$ & 42 \\
\hline Masters & 1 & $31-40$ & 2 \\
\hline Occupation: & & Severity of alcohol dependence : & \\
\hline Unemployed & 2 & Mild Dependence & 12 \\
\hline Unskilled & 32 & Moderate Dependence & 44 \\
\hline Semiskilled & 2 & Severe Dependence & 15 \\
\hline Skilled & 36 & Very Severe Dependence & 9 \\
\hline Professional & 8 & Childs' Gender: & \\
\hline Annual income: & & Male & 41 \\
\hline$<60,000$ & 17 & Female & 39 \\
\hline $60,000-1,20,000$ & 45 & & \\
\hline$>1,20,000$ & 18 & & \\
\hline
\end{tabular}


Table 2. Raw scores of YSR scales of children

\begin{tabular}{llll}
\hline & Male & Female & Total \\
\hline Aggressive behaviour & $48.7 \%(20)$ & $46.1 \%(18)$ & $47.5 \%(38)$ \\
Rule Breaking behaviour & $43.9 \%(18)$ & $46.1 \%(18)$ & $45 \%(36)$ \\
Attention Problems & $7.3 \%(3)$ & $2.5 \%(1)$ & $5 \%(4)$ \\
thought Problems & $4.8 \%(2)$ & $7.6 \%(3)$ & $6.2 \%(5)$ \\
Social Problems & $14.6 \%(6)$ & $15.3 \%(6)$ & $15 \%(12)$ \\
Somatic complaints & $34.1 \%(14)$ & $38.4 \%(15)$ & $36.2 \%(29)$ \\
Withdrawn & $34.1 \%(14)$ & $35.8 \%(14)$ & $35 \%(28)$ \\
Anxious/Depressed & $41.4 \%(17)$ & $46.1 \%(18)$ & $43.7 \%(35)$ \\
\hline
\end{tabular}

Table 3. Distribution of total externalizing scores and internalizing scores in children according to gender

\begin{tabular}{lllll}
\hline & & Male & Child's gender & P Values \\
& & Female & \\
\hline Internalization Score (Percentile) & Normal range & 29 & 13 & 0.004 \\
& Clinical Range & 12 & 26 & 0.008 \\
& Normal range & 15 & 26 & 13 \\
\hline
\end{tabular}

had aggressive behaviour, $45 \%$ had rule breaking behaviour, $5 \%$ had attention problems, $6.2 \%$ thought problems and $15 \%$ had social problems. $36.2 \%$ of these children had somatic complaints, $43.7 \%$ had anxious/depressed symptoms and had $35 \%$ withdrawn/depressed symptoms. (table 2). Of these 80 children $47.5 \%$ (38) had internalizing symptoms and $48.7 \%$ (39) had externalizing symptoms (Figure 1 and 2). It was noted that internalizing symptoms were significantly higher in females $(p=0.004)$ and externalizing symptoms were significantly higher in males $(p=0.008)$ (Table 3). However we found no significant correlation between internalizing and externalizing symptoms in children and the
Sociodemographic details (table 4 and 5), or the duration and the severity of alcohol dependence in father (table 6 and 7 ).

\section{DISCUSSION}

\section{Socio-demographic data:}

Alcohol consumption and problems related to alcohol vary widely around the world, but the burden of disease and death remains significant in most countries. Alcohol consumption is the world's third largest risk factor for disease and disability; in middleincome countries, it is the greatest risk. In a WHO study conducted in 2014, in India on an average $3.8 \%$ of the male population had a dependence

Table 4. Correlation of internalizing behaviour with the sociodemogaphic details

\begin{tabular}{|c|c|c|c|c|}
\hline & & \multicolumn{2}{|c|}{ Internalization (Percentile) } & \\
\hline & & Normal range & Clinical range & \\
\hline \multirow[t]{4}{*}{ Father's Age } & $30-35$ & 3 & 7 & 0.310 \\
\hline & $36-40$ & 15 & 8 & \\
\hline & $41-45$ & 13 & 13 & \\
\hline & $46-50$ & 11 & 10 & \\
\hline \multirow[t]{5}{*}{ Father's education } & Illitrate & 8 & 13 & 0.504 \\
\hline & Primary & 15 & 10 & \\
\hline & Secondary & 15 & 12 & \\
\hline & Bachelors & 3 & 3 & \\
\hline & Masters & 1 & 0 & \\
\hline \multirow[t]{5}{*}{ Father's occupation } & Un-employed & 1 & 1 & 0.159 \\
\hline & Un-skilled & 12 & 20 & \\
\hline & Semi-skilled & 23 & 13 & \\
\hline & Skilled & 2 & 0 & \\
\hline & Professional & 4 & 4 & \\
\hline \multirow[t]{2}{*}{ Residence } & Rural & 12 & 10 & 0.821 \\
\hline & Urban & 30 & 28 & \\
\hline
\end{tabular}




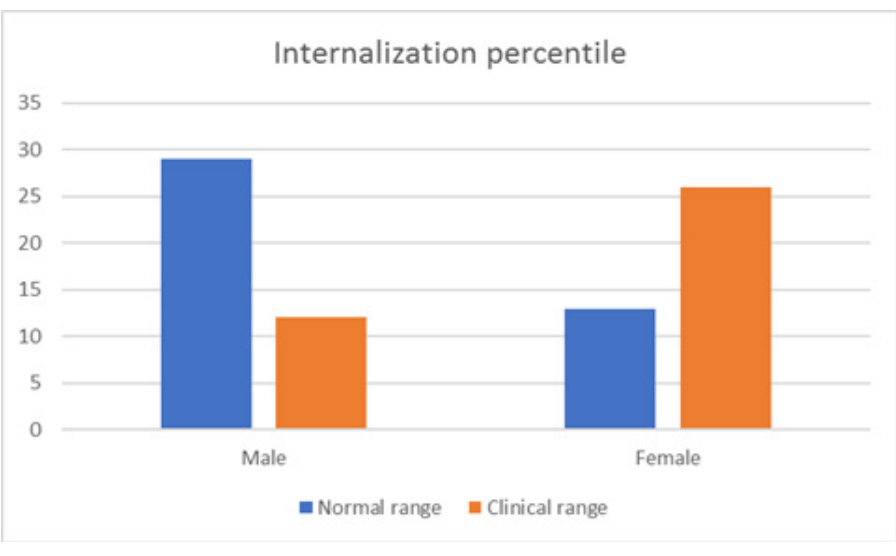

Figure 1. Distribution of internalization percentile according to child's gender

pattern in alcohol consumption, among whom $12.9 \%$ were heavy drinkers(14). Studies in northern India found the 1 year prevalence of alcohol use to be between 25 and 40\%(15,16). In India, the prevalence of alcohol harmful use and Alcohol Dependence is higher among the poor sections of the society(17). Among men, very excessive drinking is found to be higher in low educational groups, while 'Psychological Dependence' is higher in intermediate educational groups (18). Harmful drinking and Alcohol Dependence is higher in physically strenuous occupations. The prevalence of hazardous drinking among industrial workers in Goa is $21 \%(19)$. Alcohol Dependence vary in urban, rural, town and slum populations. Even

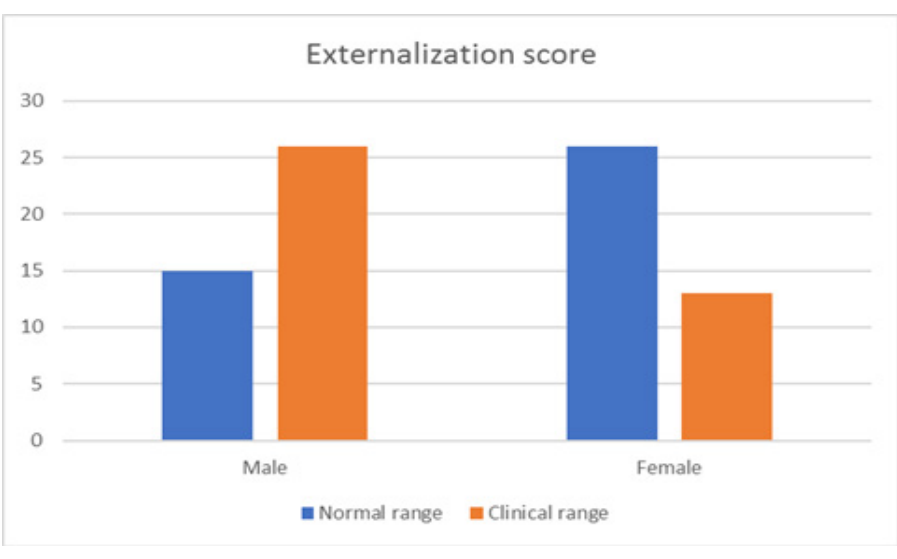

Figure 2. Distribution of externalization percentile according to child's gender

though the proportion of alcohol users is greater in towns, frequent heavy drinking is higher in slum and rural areas (20).

In a south Indian study conducted in Thiruvananthapuram, it was found that mean age of alcohol dependent men was 42.5 years(SD 17.2), with $2 / 3$ rd of the participants in study working in informal sector(manual labour, head load work, carpentry, construction work) (21) Among them $38.41 \%$ were severely dependent on alcohol. In a WHO sponsored study conducted in Bangalore (22) of the total alcohol users included in the survey, $17 \%$, were classified as dependent users based on ICD 10. Nearly two thirds of the users $(67.4 \%)$ were in the age

Table 5. Correlation of externalizing behaviour with the sociodemogaphic details

\begin{tabular}{|c|c|c|c|c|}
\hline \multirow[b]{3}{*}{ Father's Age } & & \multicolumn{2}{|c|}{ Externaliziation (Percentile) } & \multirow[b]{3}{*}{.096} \\
\hline & & Normal range & Clinical range & \\
\hline & $30-35$ & 8 & 2 & \\
\hline & $36-40$ & 8 & 15 & \\
\hline & $41-45$ & 15 & 11 & \\
\hline & $46-50$ & 10 & 11 & \\
\hline \multirow[t]{5}{*}{ Father's education } & Illitrate & 13 & 8 & .011 \\
\hline & Primary & 9 & 16 & \\
\hline & Secondary & 18 & 9 & \\
\hline & Bachelors & 0 & 6 & \\
\hline & Masters & 1 & 0 & \\
\hline \multirow[t]{5}{*}{ Father's occupation } & Un-employed & 2 & 0 & 135 \\
\hline & Un-skilled & 17 & 15 & \\
\hline & Semi-skilled & 20 & 16 & \\
\hline & Skilled & 1 & 1 & \\
\hline & Professional & 1 & 7 & \\
\hline \multirow{2}{*}{ Residence } & Rural & 14 & 8 & 0.172 \\
\hline & Urban & 27 & 31 & \\
\hline
\end{tabular}


Table 6. Correlation between child's internalization percentile and duration and severity of fathers alcohol dependence

\begin{tabular}{llccc}
\hline & & \multicolumn{2}{c}{$\begin{array}{c}\text { Internalization (Percentile) } \\
\text { Clinical range }\end{array}$} \\
\hline Duration of alcohol consumption & $0-10$ & Normal range & 1 & 0.819 \\
& $11-20$ & 17 & 15 & \\
Severity of alcohol dependence & $21-30$ & 21 & 1 & \\
& $31-40$ & 1 & 3 & 0.86 \\
& & & 9 & \\
& Mild & 5 & 14 & \\
\hline
\end{tabular}

Table 7. Correlation between child's externalization percentile and duration and severity of fathers alcohol dependence

\begin{tabular}{llccc}
\hline & & \multicolumn{2}{c}{$\begin{array}{c}\text { Externaliziation (Percentile) } \\
\text { Clinical range }\end{array}$} \\
\hline Duration of alcohol consumption & $0-10$ & 3 & 1 & 0.121 \\
& $11-20$ & 20 & 12 & \\
Severity of alcohol dependence & $21-30$ & 18 & 24 & \\
& $31-40$ & 0 & 0 & 0.95 \\
& Mild & 7 & 10 & 11 \\
& Moderate & 8 & 15 & 17
\end{tabular}

group of 26 to 45 years. The user population includes a greater proportion of unskilled workers (25.4\%). Prevalence of alcohol use was almost similar in rural and urban population $(16.2 \%, 12 \%)$ in the middleaged population.

In our study, mean age of the alcohol dependent father was 41.9 years and $53 \%$ of the patients had completed at least their secondary education. $85 \%$ of the patients were either unskilled or semi-skilled workers, while only $10 \%$ of them were professionals. In our patient population most of them (72\%) were residing in urban areas. $30 \%$ of the patient population had severe to very severe dependence according to SADQ questionnaire. This change in sociodemographic pattern in our study can be attributed to the fact that study was conducted in an urban, tertiary care centre.

\section{Psychological profile of children:}

Internalizing psychopathology encompasses symptoms such as anxiety and depression and externalizing psychopathology primarily encompasses "acting out" types of behaviour-characterized by rule breaking, defiance, aggression, inattention, and impulsivity.

In an Indian study estimating the prevalence of behavioural problems in adolescent children in general population(23), internalizing behaviour was found in $9 \%$ of the children and externalizing behaviour in $9.5 \%$ of the children. A study in tertiary care centre in Pune (24), examined the internalizing and externalizing symptoms in 25 children of alcohol dependent parents belonging to age group of 6-18 years using Child Behavior Check List. They analysed the results in 2 groups (6-11 years and 12-18 years). In the age group of 12-18 years, the study showed that the internalizing as well as the externalizing scores of the children of alcohol dependent parents was greater than the normal scores of the matched population on the CBCL. The girls had more internalizing problems as compared to boys who had more externalizing problems.

Another Indian study conducted by Raj et al. (25) which also used CBCL concluded that girls had a significantly more internalizing behavioural problems than boys and externalizing problems, especially conduct problems are represented more in boys than girls of alcohol dependent parents. Although no studies were conducted in India using the same scale, Obot et al. (26) conducted such study in United States among the population sample of the National Household Survey on Drug Abuse, and compared Youth Self Report (YSR) scores of children of alcohol 
dependent parents with non-alcohol dependent parents in a community based study. The study showed that children of parents with active alcohol problems had higher scores than other children on aggressive problems, anxious-depressed, attention problems, and social problems. There was no statistically significant relationship between parental alcohol dependence and indices of thought problems, somatic complaints or being withdrawn.

In our study, of the 80 children $47.5 \%$ had clinically significant scores in internalization with significantly higher correlation with female children than males. Also $48.7 \%$ had clinically significant externalizing symptoms with significantly higher correlation to male children. Among the areas analysed, these children showed disturbance / symptoms in dimensions of anxious/depression, withdrawn, and aggressive behaviour. There were no significant symptoms in dimensions of somatic complaints, social problems, thought problems, attention problems and delinquent behaviour. The internalizing and externalizing scores were much higher than in general population. The findings of our study are in concordance with the above-mentioned studies.

\section{Association of children's psychological profiles with parental factors:}

Hussong et al examined the longitudinal correlation of children's externalizing and internalizing symptoms, and socio-demographic details, parental alcohol dependence pattern and severity. They also assessed the fluctuation in child's symptoms with parents alcohol pattern (27-29). In their study higher levels of parental education were associated with lower levels of internalizing at age 13. None of the remaining relations between demographic covariates and the growth factors was significant. They also found consistent and large number of children of alcohol dependents had greater risk for externalizing symptoms than children of non-alcohol dependents. In addition, they also correlated child's externalizing symptoms with greater alcohol-related symptoms during the study period when externalizing symptoms were assessed, i.e., during periods of severe dependence in parent there was increased externalizing symptoms in children. However, they found higher risk of internalizing symptoms in children of alcohol dependent parents, they could not find any correlation between children's internalizing symptoms and severity of alcohol dependence.

In India Raman et al. (30) analysed the psychopathology of children of alcohol dependent parents of age group 5-9 years and their correlation with severity of alcohol dependence and found that higher externalizing behaviour were seen in children of parents with higher levels of alcohol dependence. No significant relation was found between internalizing symptoms and severity of alcohol dependence.

In our study no significant association was found between socio- demographic variables and externalizing behaviours. There was also no significant correlation found between internalizing and externalizing behaviours and duration or severity of illness. As previous studies were mainly done in the west, further studies have to be in conducted in our population to assess the confounding/ protective factors.

\section{Implication:}

As there is a high prevalence of psychological disturbances in the children of alcohol dependent individuals it would be imperative to consider routine screening of these individuals, which would further help in developing strategies for prevention, early identification, and timely intervention.

\section{Limitations:}

- The findings from this study cannot be generalised as the sample was collected from a highly specific group of individuals (patients and their children who sought help from a tertiary care centre for substance dependence) and was a descriptive study. Case control studies/ community-based studies have to be conducted in this area for generalization of the results. - Other factors that might affect the occurrence of psychological disturbance in child were not studied.

- All the assessments were based on self-reports and may not reflect the true estimate of both the dependence on alcohol as well as the psychological profile of the child.

Conflict of interest: Authors declare that there is no conflict of interest between the authors of the article.

Financial conflict of interest: Authors declare that they did not receive any financial support in this study.

Address correspondence to: Manju Aswath, Department of Psychiatry, Kempegowda Institute of Medical Sciences and Research Center, Rajiv Gandhi University of Health Sciences, V V Puram, Bangalore

e-mail: manjuaswath@yahoo.com

Phone: +919880476580

\section{REFERENCES}

1. Mattoo SK, Nebhinani N, Kumar BNA, et al. Family burden with substance dependence: A study from India. Indian J 
Med Res 2013;137(4):704.

2. Moos RH, Billings AG. Children of alcoholics during the recovery process: Alcoholic and matched control families. Addict Behav 1982;7(2):155-63.

3. Roosa MW, Michaels M, Groppenbacher N, et al. Validity of children's reports of parental alcohol abuse. J Stud Alcohol 1993;54(1):71-9.

4. Conger RD, Patterson GR, Ge X. It takes two to replicate: A mediational model for the impact of parents' stress on adolescent adjustment. Child Dev 1995;66(1):80-97.

5. Birmaher B, Ryan ND, Williamson DE, et al. Childhood and adolescent depression: A review of the past 10 years. Part I. J Am Acad Child Adolesc Psychiatry 1996;35(11):1427-39.

6. Tarter RE, Blackson T, Martin C, et al. Characteristics and correlates of child discipline practices in substance abuse and normal families. Am J Addict 1993;2(1):18-25.

7. Fitzgerald HE, Sullivan LA, Ham HP, et al. Predictors of behavior problems in three-year-old sons of alcoholics: Early evidence for the onset of risk. Child Dev 1993;64(1):110-23.

8. Earls F, Reich W, Jung KG, et al. Psychopathology in Children of alcoholic and antisocial parents. Alcohol Clin Exp Res 1988;12(4):481-7.

9. Rao KN, Begum S, Venkataramana V, et al. Nutritional neglect and physical abuse in children of alcoholics. Research Gate 2001;68(9):843-5.

10. Pinto VN, Kulkarni RN. A case control study on school dropouts in children of alcohol-dependent males versus that in abstainers/social drinkers' children. J Fam Med Prim Care 2012;1(2):92.

11. Abraham J, Chandrasekaran R. The severity of alcohol dependence data questionnaire: Modification and validation. Indian J Psychiatry 1997;39(1):8-12.

12. Kamat VV. Measuring intelligence of Indian children. 4th edition. Oxford University Press, 1967.

13. Ebesutani C, Bernstein A, Martinez JI, et al. The youth self report: Applicability and validity across younger and older youths. J Clin Child Adolesc Psychol 2011;40(2):338- 46.

14. WHO | Country profiles 2014 [Internet]. [cited 2016 Oct 7]. Available from: http://www.who.int/substance_abuse/ publications/global_alcohol_report/profiles/en/

15. Mohan D, Sharma HK, Darshan S, et al. Prevalence of drug abuse in young rural males in Punjab. Indian $\mathrm{J}$ Med Res 1978;68:689-94.

16. Varma VK, Singh A, Singh S, et al. Extent and pattern of alcohol use and alcohol-related problems in north India. Indian J Psychiatry 1980;22(4):331-7.

17. Bennett LA, Jancca A, Grant BF, et al. Boundaries between normal and pathological drinking: A cross-cultural comparison. Research Gate 1993;17(3):190-5.

18. Oers JA van, Bongers IM, Goor LA van de, et al. Alcohol consumption, alcohol-related problems, problem drinking, and socioeconomic status. Alcohol Alcohol 1999;34(1):7888.

19. Chagas Silva M, Gaunekar G, Patel V, et al. The prevalence and correlates of hazardous drinking in industrial workers: A study from Goa, India. Alcohol Alcohol 2003;38(1):79-83.

20. Girish N, Kavita R, Gururaj G, et al. Alcohol use and implications for public health: Patterns of use in four communities. Indian J Community Med off Publ Indian Assoc Prev Soc Med 2010;35(2):238-44.

21. Bal R. Prevalence of alcohol dependence among males in Thiruvananthapuram district, Kerala. Res Rev J Soc
Sci2016;2(1):1-7.

22. Organization WH, Asia RO for S-E. Burden and socioeconomic impact of alcohol: The bangalore study. 2006 [cited 2016 Oct 8]; Available from: http://www.who.int/iris/ handle/10665/204856

23. Ahmad A, Khalique N, Khan Z. Behavioral and emotional problems of adolescents relationship with academic achivement. Indian J Community Health 2007;18(2):3-8.

24. Sidhu J, Dutta E, Naphade N, et al. The impact of parental alcohol dependence on the development and behavior outcome of children in a tertiary care hospital. Med J Dr Patil Univ 2016;9(1):17.

25. Raj H, Kumar K, Sinha VK, et al. A comparative study on behavioural problems in children of alcohol dependent parents. Dysphrenia 1(3):137-43.

26. Obot SI, Anthony CJ. Mental health problems in adolescent children of alcohol dependent parents: Epidemiologic research with a nationally representative sample. J Child Adolesc Subst Abuse 2004;13(4):83-96.

27. Hussong AM, Cai L, Curran PJ, et al. Disaggregating the distal, proximal, and time-varying effects of parent alcoholism on children's internalizing symptoms. J Abnorm Child Psychol 2008;36(3):335-46.

28. Hussong AM, Huang W, Curran PJ, et al. Parent alcoholism impacts the severity and timing of children's externalizing symptoms. J Abnorm Child Psychol 2010;38(3):367-80.

29. Hussong AM, Flora DB, Curran PJ, et al. Defining risk heterogeneity for Internalizing symptoms among children of alcoholic parents. Dev Psychopathol 2008;20(1):165-93.

30. Raman V, Prasad S, Appaya MP. Children of men with alcohol dependence: Psychopathology, neurodevelopment and family environment. Indian J Psychiatry 2010;52(4):3606. 